\title{
Association between Programmed Cell Death 6 Interacting Protein Insertion/Deletion Polymorphism and the Risk of Breast Cancer in a Sample of Iranian Population
}

\author{
Mohammad Hashemi, ${ }^{1,2}$ Javad Yousefi, ${ }^{3}$ Seyed Mehdi Hashemi, ${ }^{3}$ Shadi Amininia, ${ }^{2}$ \\ Mahboubeh Ebrahimi, ${ }^{2}$ Mohsen Taheri, ${ }^{4}$ and Saeid Ghavami ${ }^{5,6,7}$ \\ ${ }^{1}$ Cellular and Molecular Research Center, Zahedan University of Medical Sciences, Zahedan, Iran \\ ${ }^{2}$ Department of Clinical Biochemistry, School of Medicine, Zahedan University of Medical Sciences, Zahedan, Iran \\ ${ }^{3}$ Department of Internal Medicine, School of Medicine, Zahedan University of Medical Sciences, Zahedan, Iran \\ ${ }^{4}$ Genetic of Non-Communicable Disease Research Center, Zahedan University of Medical Sciences, Zahedan, Iran \\ ${ }^{5}$ Department of Human Anatomy and Cell Science, College of Medicine, Faculty of Health Sciences, University of Manitoba, \\ Winnipeg, MB, Canada R3E 0J9 \\ ${ }^{6}$ Manitoba Institute of Child Health, University of Manitoba, Winnipeg, MB, Canada R3E 0J9 \\ ${ }^{7}$ Health Policy Research Center, Shiraz University of Medical Sciences, Shiraz, Iran
}

Correspondence should be addressed to Mohammad Hashemi; mhd.hashemi@gmail.com

and Saeid Ghavami; saeid.ghavami@gmail.com

Received 13 January 2015; Revised 1 April 2015; Accepted 15 April 2015

Academic Editor: Grant Izmirlian

Copyright (C) 2015 Mohammad Hashemi et al. This is an open access article distributed under the Creative Commons Attribution License, which permits unrestricted use, distribution, and reproduction in any medium, provided the original work is properly cited.

\begin{abstract}
It has been suggested that genetic factors contribute to patients' vulnerability to breast cancer (BC). The programmed cell death 6 interacting protein (PDCD6IP) encodes for a protein that is known to bind to the products of the PDCD6 gene, which is involved in the apoptosis pathway. The aim of this case-control study is to investigate the relationship between the PDCD6IP $15 \mathrm{bp}$ insertion/deletion (I/D) polymorphism (rs28381975) and BC risk in an Iranian population. A total of 491 females, including 266 BC patients and 225 control subjects without cancer, were enrolled into the study. Our findings revealed that the PDCD6IP 15 bp I/D polymorphism decreased the risk of $\mathrm{BC}$ in codominant $(\mathrm{OR}=0.44,95 \% \mathrm{CI}=0.31-0.65, p<0.0001, \mathrm{I} / \mathrm{D}$ versus $\mathrm{DD}$; OR $=0.39$, $95 \% \mathrm{CI}=0.17-0.88, p=0.030, \mathrm{I} / \mathrm{I}$ versus $\mathrm{DD})$ and dominant $(\mathrm{OR}=0.44,95 \% \mathrm{CI}=0.30-0.63, p<0.0001, \mathrm{D} / \mathrm{I}+\mathrm{I} / \mathrm{I}$ versus $\mathrm{D} / \mathrm{D})$ tested inheritance models. Also, the PDCD6IP I allele significantly decreased the risk of $\mathrm{BC}(\mathrm{OR}=0.59,95 \% \mathrm{CI}=0.45-0.78$, $p<0.001$ ) compared to the $\mathrm{D}$ allele.
\end{abstract}

\section{Introduction}

Breast cancer $(\mathrm{BC})$ is the most common cancer and the second leading cause of cancer death among women. It is recognized as an important health care problem worldwide, affecting more than 1 million women annually [1-3]. BC is one of the most frequent malignancies among Iranian women, and it comprises $21.4 \%$ of female cancers [4]. It has been proposed that $\mathrm{BC}$ affects Iranian women about a decade earlier than women of western countries [5]. BC is known as a multifactor disease and its exact etiology is still unknown.
We have previously investigated polymorphisms of human telomerase reverse transcriptase, cyclin E1, and lysosomeassociated protein transmembrane 4 beta in $\mathrm{BC}$ and showed that genetic factors play important roles in the pathogenesis and progress of this malignancy $[3,6-8]$.

In humans, programmed cell death 6 interacting protein (PDCD6IP), which is also known as AIP1 (ALG2-interacting protein 1) and ALIX (ALG2-interacting protein 1), is mapped on chromosome 3p22.3. This gene in responsible for biosynthesis of a protein that is involved in protein transport and trafficking in the cells and it has several functions, 
including the abscission stage of cytokinesis, intraluminal endosomal vesicle formation, and enveloped virus budding [9]. In addition, the product of this gene binds to the product of the PDCD6 gene, a protein needed for apoptosis, in a calcium-dependent manner.

Apoptosis (programmed cell death I) is a tightly regulated pathway, which is involved in organism cell death [1012]. Many factors play critical roles in apoptosis including, caspases $[13,14]$, pro- and antiapoptotic $\mathrm{Bcl} 2$ family proteins [15-17], and mitochondria proapoptotic proteins [18, 19]. Apoptosis imbalance has been reported to be critical in different cancers [14], and therefore many anticancer agents have been designed to target various apoptotic proteins/genes $[20,21]$.

Currently, little information is available regarding the association between PDCD6IP polymorphisms and cancer risk $[9,22]$. To the best of our knowledge, there are no reports regarding the association between the $15 \mathrm{bp} I / D$ variant within the $P D C D 6 I P$ promoter and BC susceptibility. Therefore, in this study, we aimed to evaluate the impact of the PDCD6IP 15 bp I/D polymorphism on BC susceptibility in a sample of Iranian women.

\section{Materials and Methods}

2.1. Patients. This case-control study was performed in a southeast Iranian population, and 266 female BC patients and 225 female age-matched control subjects with no history of any types of cancer were enrolled into the study. Ethics approval for recruitment was obtained from the Local Ethics Committee of Zahedan University of Medical Sciences, and written informed consent was obtained from all patients and healthy individuals.

Blood samples were collected from patients and healthy controls, using EDTA-containing tubes, and DNA was extracted using the salting-out method, as described previously [23]. The quality of isolated DNA was assessed using electrophoresis on $1 \%$ agarose gel, quantitated spectrophotometrically, and stored at $-20^{\circ} \mathrm{C}$ until further use.

2.2. Genotyping of $15 \mathrm{bp} I / D$ PDCD6IP Polymorphism. The polymerase chain reaction (PCR) was used for genotyping the $15 \mathrm{bp}$ I/D PDCD6IP polymorphism using forward and reverse primer sequences as follows: $5^{\prime}$-ACCTGACAGTAAGCTGCACG-3' $3^{\prime}$ and $5^{\prime}$-GGCAGTCCCAGGGTTATTGT-3', respectively. PCR reactions consisted of a total volume of $20 \mu \mathrm{L}$ containing $250 \mu \mathrm{MdNTPs}, 0.5 \mu \mathrm{M}$ of each primer, $1.5 \mathrm{mM} \mathrm{MgCl}_{2}$, $1 \mathrm{UTaq}$ DNA polymerase, and 100 ng genomic DNA. The PCR cycling conditions consisted of an initial denaturing step for $5 \mathrm{~min}$ at $95^{\circ} \mathrm{C}$ followed by 30 cycles for $30 \mathrm{~s}$ at $95^{\circ} \mathrm{C}, 30 \mathrm{~s}$ at $60^{\circ} \mathrm{C}$, and $30 \mathrm{~s}$ at $72^{\circ} \mathrm{C}$, as well as a final extension step for $10 \mathrm{~min}$ at $72^{\circ} \mathrm{C}$. The PCR products were visualized on a $3 \%$ agarose gel containing $0.5 \mu \mathrm{g} / \mathrm{mL}$ of ethidium bromide and genotypes were determined (Figure 1). To certify genotyping quality, $20 \%$ of random samples were regenotyped and the results confirmed the previous genotyping outcomes (100\% match).

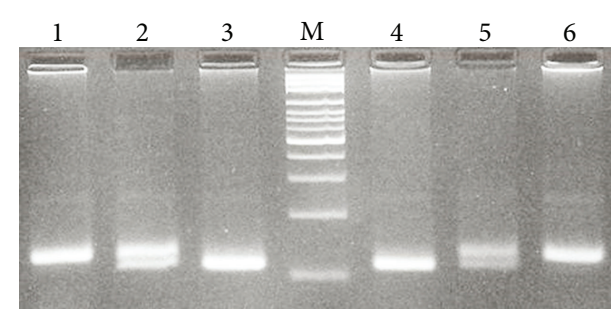

Figure 1: Photograph of the PDCD6IP 15 bp I/D (rs28381975) polymorphism PCR product. M: $100 \mathrm{bp}$ DNA marker; lanes 1 and 6: I/I; lanes 2 and 5: I/D; lanes 3 and 4: D/D.

2.3. Statistical Analysis. Statistical analysis was performed using the statistical package, SPSS 18 software. Demographic and biochemical parameters between the groups were analyzed using an independent sample $t$-test for continuous data and the $\chi^{2}$ test for categorical data. The association between genotypes and $\mathrm{BC}$ was assessed by computing the odds ratio (OR) and 95\% confidence intervals (95\% CI) from logistic regression analyses. $p<0.05$ was considered to be significant.

\section{Results}

The study group consisted of 266 female BC patients with an average age of $48.9 \pm 11.1$ years and 225 healthy females with a mean age of $50.0 \pm 12.9$ years. No significant difference in age was found between the groups $(p=0.306)$. The frequency distribution of the PDCD6IP $15 \mathrm{bp}$ I/D genotypes in $\mathrm{BC}$ patients and control subjects is shown in Table 1. Our findings revealed that the PDCD6IP $15 \mathrm{bp} \mathrm{I/D} \mathrm{polymorphism}$ decreased the risk of $\mathrm{BC}$ in codominant $(\mathrm{OR}=0.44,95 \% \mathrm{CI}=$ $0.31-0.65, p<0.0001, \mathrm{I} / \mathrm{D}$ versus $\mathrm{DD} ; \mathrm{OR}=0.39,95 \% \mathrm{CI}=$ $0.17-0.88, p=0.030, \mathrm{I} / \mathrm{I}$ versus $\mathrm{DD})$ and dominant $(\mathrm{OR}=$ $0.44,95 \% \mathrm{CI}=0.30-0.63, p<0.0001, \mathrm{D} / \mathrm{I}+\mathrm{I} / \mathrm{I}$ versus $\mathrm{D} / \mathrm{D})$ tested inheritance models. In addition, the PDCD6IP I allele significantly decreased the risk of $\mathrm{BC}(\mathrm{OR}=0.59,95 \% \mathrm{CI}=$ $0.45-0.78, p<0.001)$, compared to the D allele.

We also examined the impact of the PDCD6IP $15 \mathrm{bp} \mathrm{I/D}$ polymorphism and patients' clinicopathologic characteristics (Table 2). The results indicate that there is no significant association between this variant and age, pathological type, tumor size, grade, stage, estrogen receptor, progesterone receptor, and HER2 status $(p>0.05)$.

\section{Discussion}

In the present study, we investigated the impact of PDCD6IP $15 \mathrm{bp} \mathrm{I/D}$ on $\mathrm{BC}$ risk in a sample of Iranian women. Our results indicated that the $P D C D 6 I P 15 \mathrm{bp} \mathrm{I/D}$ polymorphism decreased the risk of $\mathrm{BC}$ in codominant and dominant tested inheritance models. Similarly, the PDCD6IP I allele significantly decreased the risk of $\mathrm{BC}$ compared to the $\mathrm{D}$ allele. Moreover, we analyzed the association between the PDCD6IP 15 bp I/D polymorphism and clinicopathological characteristics of BC patients. The findings showed no significant association between the variant and clinicopathological characteristics. 
TABLE 1: The genotypes and allele distribution of PCD6IP 15 bp I/D (rs28381975) variants in breast cancer (BC) patients and the control group.

\begin{tabular}{|c|c|c|c|c|}
\hline PCD6IP & $\begin{array}{c}\text { Patients } \\
n(\%)\end{array}$ & $\begin{array}{c}\text { Control group } \\
n(\%)\end{array}$ & OR (95\% CI) & $p$ value \\
\hline \multicolumn{5}{|l|}{ Codominant } \\
\hline $\mathrm{D} / \mathrm{D}$ & $139(52.3)$ & $73(32.4)$ & 1.00 & - \\
\hline $\mathrm{I} / \mathrm{D}$ & $116(43.6)$ & $137(60.9)$ & $0.44(0.31-0.65)$ & $<0.0001$ \\
\hline $\mathrm{I} / \mathrm{I}$ & $11(4.1)$ & $15(6.7)$ & $0.39(0.17-0.88)$ & 0.030 \\
\hline \multicolumn{5}{|l|}{ Dominant } \\
\hline $\mathrm{D} / \mathrm{D}$ & $139(52.3)$ & $73(32.4)$ & 1.00 & - \\
\hline $\mathrm{D} / \mathrm{I}+\mathrm{I} / \mathrm{I}$ & $127(47.7)$ & $152(67.6)$ & $0.44(0.30-0.63)$ & $<0.0001$ \\
\hline \multicolumn{5}{|l|}{ Recessive } \\
\hline $\mathrm{D} / \mathrm{D}+\mathrm{D} / \mathrm{I}$ & $256(95.9)$ & $210(93.3)$ & 1.00 & - \\
\hline $\mathrm{I} / \mathrm{I}$ & $11(4.1)$ & $15(6.7)$ & $0.60(0.27-1.34)$ & 0.229 \\
\hline \multicolumn{5}{|l|}{ Allele } \\
\hline $\mathrm{D}$ & $394(74.1)$ & $283(62.9)$ & 1.00 & - \\
\hline $\mathrm{I}$ & $138(25.9)$ & $167(37.1)$ & $0.59(0.45-0.78)$ & $<0.001$ \\
\hline
\end{tabular}

TABLE 2: Association between the PDCD6IP 15 bp I/D polymorphism and clinicopathological characteristics.

\begin{tabular}{|c|c|c|c|c|}
\hline \multirow{2}{*}{ Variables } & \multicolumn{3}{|c|}{ PDCD6IP 15 bp I/D } & \multirow{2}{*}{$p$ value } \\
\hline & $\mathrm{D} / \mathrm{D}$ & $\mathrm{I} / \mathrm{D}$ & $\mathrm{I} / \mathrm{I}$ & \\
\hline Age (years) & & & & 0.757 \\
\hline$\leq 50$ & 75 & 66 & 7 & \\
\hline$>50$ & 61 & 46 & 4 & \\
\hline Pathological type & & & & 0.909 \\
\hline Ductal & 83 & 63 & 6 & \\
\hline Others & 42 & 34 & 4 & \\
\hline Tumor size $(\mathrm{cm})$ & & & & 0.111 \\
\hline$\leq 2$ & 55 & 31 & 2 & \\
\hline$>2$ & 72 & 66 & 8 & \\
\hline TNM stage & & & & 0.388 \\
\hline I & 33 & 18 & 0 & \\
\hline II & 50 & 38 & 5 & \\
\hline III & 35 & 31 & 3 & \\
\hline IV & 17 & 18 & 3 & \\
\hline Grade & & & & 0.989 \\
\hline I & 27 & 20 & 2 & \\
\hline II & 71 & 47 & 6 & \\
\hline III + IV & 18 & 13 & 1 & \\
\hline Estrogen receptor & & & & 0.625 \\
\hline Positive & 69 & 54 & 5 & \\
\hline Negative & 43 & 42 & 5 & \\
\hline Progesterone receptor & & & & 0.460 \\
\hline Positive & 63 & 56 & 7 & \\
\hline Negative & 48 & 38 & 2 & \\
\hline HER2 & & & & 0.141 \\
\hline Positive & 76 & 47 & 6 & \\
\hline Negative & 57 & 59 & 5 & \\
\hline
\end{tabular}


To date, there have only been two reports that investigated the association between PDCD6IP $15 \mathrm{bp} \mathrm{I/D} \mathrm{and} \mathrm{cancer} \mathrm{risk.}$ $\mathrm{Yu}$ et al. [22] evaluated the possible association between the PDCD6IP 15 bp I/D polymorphism and hepatocellular carcinoma (HCC). They found that subjects carrying I/D or I/I genotype had a significantly increased risk for HCC compared to individuals carrying the $\mathrm{D} / \mathrm{D}$ genotype $(\mathrm{OR}=$ $1.39,95 \% \mathrm{CI}=1.01-1.91, p=0.033)$. The $15 \mathrm{bp}$ insertion allele was associated with a 1.26-fold risk for HCC (95\% $\mathrm{CI}=1.04-1.54, p=0.018$ ). Liu et al. [9] investigated the association between the PDCD6IP $15 \mathrm{bp} \mathrm{I/D} \mathrm{polymorphism}$ and non-small-cell lung cancer (NSCLC) in the Chinese Han population. They found that the PDCD6IP $15 \mathrm{bp}$ I/D variant increased the risk NSCLC in a dominant inheritance model $(\mathrm{OR}=1.72,95 \% \mathrm{CI}=1.29-2.31, p<0.01$, ID + II versus DD). The PDCD6IP I allele was significantly associated with the risk of NSCLC $(\mathrm{OR}=1.41,95 \% \mathrm{CI}=1.18-1.69, p<$ 0.01 ). They also found that the PDCD6IP I/D polymorphism significantly increased the risk of advanced NSCLC [9]. It has been shown that the PDCD6IP rs1127732 C/T polymorphism is associated with $\mathrm{BC}$ [24]. Another genome-wide linkage analysis of bipolar disorder showed that the rs1127732 C/T variant increased the risk of bipolar disorder [25].

The PDCD6IP I allele has been shown to be associated with enhanced promoter activity [9]. Overexpression of PDCD6IP restores contact inhibition, promotes detachmentinduced apoptosis, and reduces tumorigenicity in nude mice $[26,27]$. Overexpression of an AIP1 deletion mutant protects HeLa and COS cells from apoptosis induced by serum starvation; thus, AIP1 might mediate, at least in part, the ALG-2 requirement for apoptosis [28]. Therefore, it can be concluded that PDCD6IP might be involved in regulation of apoptosis and that it might affect the balance between cell death and cell proliferation; thus, $P D C D 6 I P$ could be involved in carcinogenesis. We showed that the PDCD6IP 15 bp I/D polymorphism decreased the risk of $\mathrm{BC}$ in codominant and dominant tested inheritance models, while the above two studies highlighted that the PDCD6IP $15 \mathrm{bp}$ I/D polymorphism increases the risk of HCC and NSCLC in a Chinese population. Based on this controversy, we can conclude that the PDCD6IP gene product might have different effects on the regulation of apoptosis in different populations or that apoptosis might have different regulatory effects on cancer progress in different types of cancer.

It is well known that mutations lead to BC; however, other changes, such as chromosomal rearrangements, may lead to differential expression of oncogenes and tumor suppressor genes. Two BC susceptibility genes (BRCA1 and BRCA2) have been identified, and germline mutations in these genes are thought to account for between $5 \%$ and $10 \%$ of all BC cases [29]. Frameshift mutations as well as missense mutations are known to alter protein function. Defects in the biological action of the genome that are driven by various alterations, such as point mutations and chromosomal rearrangements, lead to the collapse of genome integrity, uncontrolled cell proliferation, and failure of apoptotic cell death [30].

A limitation of this study is that we did not use the association between several genes together and the $\mathrm{BC}$ outcome in the statistical analysis; this may cause different results.

In conclusion, our findings indicate that the PDCD6IP $15 \mathrm{bp} \mathrm{I/D} \mathrm{polymorphism} \mathrm{decreases} \mathrm{the} \mathrm{risk} \mathrm{of} \mathrm{BC}$ in an Iranian population. Further studies with different ethnicities are required to confirm our findings.

\section{Conflict of Interests}

The authors declare that there is no conflict of interests to disclose.

\section{Authors' Contribution}

Mohammad Hashemi and Saeid Ghavami have equal senior authorship.

\section{Acknowledgments}

This paper was funded as a dissertation grant (M.D. thesis of Javad Yousefi) from the Deputy for Research, Zahedan University of Medical Sciences. Saeid Ghavami was supported by a University of Manitoba start-up grant. The authors would like to thank Dr. Jodi Smith for proofreading assistance.

\section{References}

[1] G. Turashvili, J. Bouchal, G. Burkadze, and Z. Kolar, "Differentiation of tumours of ductal and lobular origin: II. Genomics of invasive ductal and lobular breast carcinomas," Biomedical Papers of the Medical Faculty of the University Palacký, vol. 149, no. 1, pp. 63-68, 2005.

[2] J. T. Wu and J. G. Kral, “The NF- $\kappa \mathrm{B} / \mathrm{I} \kappa \mathrm{B}$ signaling system: a molecular target in breast cancer therapy," Journal of Surgical Research, vol. 123, no. 1, pp. 158-169, 2005.

[3] M. Hashemi, S. Amininia, M. Ebrahimi, S. M. Hashemi, M. Taheri, and S. Ghavami, "Association between hTERT polymorphisms and the risk of breast cancer in a sample of Southeast Iranian population," BMC Research Notes, vol. 7, no. 1, article 895, 2014.

[4] G. R. Babu, G. Samari, S. P. Cohen et al., "Breast cancer screening among females in iran and recommendations for improved practice: a review," Asian Pacific Journal of Cancer Prevention, vol. 12, no. 7, pp. 1647-1655, 2011.

[5] S. Kolahdoozan, A. Sadjadi, A. R. Radmard, and H. Khademi, "Five common cancers in Iran," Archives of Iranian Medicine, vol. 13, no. 2, pp. 143-146, 2010.

[6] M. Hashemi, A. Fazaeli, S. Ghavami et al., "Functional polymorphisms of FAS and FASL gene and risk of breast cancer-pilot study of 134 cases," PLoS ONE, vol. 8, no. 1, Article ID e53075, 2013.

[7] M. Hashemi, M. E. Omrani, E. Eskanadri-Nasab, S. S. Hasani, M. A. Mashhadi, and M. Taheri, "A 40-bp insertion/deletion polymorphism of murine double minute2 (MDM2) increased the risk of breast cancer in Zahedan, Southeast Iran," Iranian Biomedical Journal, vol. 18, no. 4, pp. 245-249, 2014.

[8] M. Omrani, M. Hashemi, E. Eskandari-Nasab et al., "Hsa-mir499 rs3746444 gene polymorphism is associated with susceptibility to breast cancer in an Iranian population," Biomarkers in Medicine, vol. 8, no. 2, pp. 259-267, 2014. 
[9] S.-G. Liu, S.-H. Yuan, H.-Y. Wu, C.-S. Huang, and J. Liu, “The programmed cell death 6 interacting protein insertion/deletion polymorphism is associated with non-small cell lung cancer risk in a Chinese Han population," Tumor Biology, vol. 35, no. 9, pp. 8679-8683, 2014.

[10] I. Rashedi, S. Panigrahi, P. Ezzati, S. Ghavami, and M. Los, "Autoimmunity and apoptosis-therapeutic implications," Current Medicinal Chemistry, vol. 14, no. 29, pp. 3139-3151, 2007.

[11] W. Chaabane, A. Cieślar-Pobuda, M. El-Gazzah et al., "Humangyrovirus-Apoptin triggers mitochondrial death pathwayNur77 is required for apoptosis triggering," Neoplasia, vol. 16, no. 9, pp. 679-693, 2014.

[12] O. M. Rollano Peñaloza, M. Lewandowska, J. Stetefeld et al., "Apoptins: selective anticancer agents," Trends in Molecular Medicine, vol. 20, no. 9, pp. 519-528, 2014.

[13] S. Ghavami, C. Kerkhoff, M. Los, M. Hashemi, C. Sorg, and F. Karami-Tehrani, "Mechanism of apoptosis induced by S100A8/A9 in colon cancer cell lines: the role of ROS and the effect of metal ions," Journal of Leukocyte Biology, vol. 76, no. 1, pp. 169-175, 2004.

[14] S. Ghavami, M. Hashemi, S. R. Ande et al., "Apoptosis and cancer: mutations within caspase genes," Journal of Medical Genetics, vol. 46, no. 8, pp. 497-510, 2009.

[15] S. Ghavami, M. M. Mutawe, K. Hauff et al., "Statin-triggered cell death in primary human lung mesenchymal cells involves p53-PUMA and release of Smac and Omi but not cytochrome c," Biochimica et Biophysica Acta, vol. 1803, no. 4, pp. 452-467, 2010.

[16] S. Ghavami, M. M. Mutawe, P. Sharma et al., "Mevalonate cascade regulation of airway mesenchymal cell autophagy and apoptosis: a dual role for p53," PLoS ONE, vol. 6, no. 1, Article ID e16523, 2011.

[17] S. Ghavami, P. Sharma, B. Yeganeh et al., "Airway mesenchymal cell death by mevalonate cascade inhibition: integration of autophagy, unfolded protein response and apoptosis focusing on Bcl2 family proteins," Biochimica et Biophysica Acta: Molecular Cell Research, vol. 1843, no. 7, pp. 1259-1271, 2014.

[18] S. Ghavami, C. Kerkhoff, W. J. Chazin et al., "S100A8/9 induces cell death via a novel, RAGE-independent pathway that involves selective release of Smac/DIABLO and Omi/HtrA2," Biochimica et Biophysica Acta: Molecular Cell Research, vol. 1783, no. 2, pp. 297-311, 2008.

[19] S. Ghavami, S. Shojaei, B. Yeganeh et al., "Autophagy and apoptosis dysfunction in neurodegenerative disorders," Progress in Neurobiology, vol. 112, pp. 24-49, 2014.

[20] S. Dasari and P. B. Tchounwou, "Cisplatin in cancer therapy: molecular mechanisms of action," European Journal of Pharmacology, vol. 740, pp. 364-378, 2014.

[21] M. Hassan, H. Watari, A. AbuAlmaaty, Y. Ohba, and N. Sakuragi, "Apoptosis and molecular targeting therapy in cancer," BioMed Research International, vol. 2014, Article ID 150845, 23 pages, 2014.

[22] Q. Yu, C. Zhou, J. Wang, L. Chen, S. Zheng, and J. Zhang, "A functional insertion/deletion polymorphism in the promoter of PDCD6IP is associated with the susceptibility of hepatocellular carcinoma in a Chinese population," DNA and Cell Biology, vol. 32, no. 8, pp. 451-457, 2013.

[23] M. Hashemi, E. Eskandari-Nasab, A. Fazaeli et al., "Association of genetic polymorphisms of glutathione-S-transferase genes (GSTT1, GSTM1, and GSTP1) and susceptibility to nonalcoholic fatty liver disease in Zahedan, Southeast Iran," DNA and Cell Biology, vol. 31, no. 5, pp. 672-677, 2012.
[24] A. Gonzalez-Neira, J. M. Rosa-Rosa, A. Osorio et al., "Genomewide high-density SNP linkage analysis of non-BRCA1/2 breast cancer families identifies various candidate regions and has greater power than microsatellite studies," BMC Genomics, vol. 8, article 299, 2007.

[25] J. A. Badner, D. Koller, T. Foroud et al., "Genome-wide linkage analysis of 972 bipolar pedigrees using single-nucleotide polymorphisms," Molecular Psychiatry, vol. 17, no. 8, pp. 818-826, 2012.

[26] Y. Wu, S. Pan, S. Che et al., "Overexpression of Hp95 induces G1 phase arrest in confluent HeLa cells," Differentiation, vol. 67, no. 4-5, pp. 139-153, 2001.

[27] Y. Wu, S. Pan, W. Luo, S.-H. Lin, and J. Kuang, "Hp95 promotes anoikis and inhibits tumorigenicity of HeLa cells," Oncogene, vol. 21, no. 44, pp. 6801-6808, 2002.

[28] P. Vito, L. Pellegrini, C. Guiet, and L. D’Adamio, "Cloning of AIP1, a novel protein that associates with the apoptosis-linked gene ALG-2 in a Ca2+-dependent reaction," The Journal of Biological Chemistry, vol. 274, no. 3, pp. 1533-1540, 1999.

[29] A. M. Martin and B. L. Weber, "Genetic and hormonal risk factors in breast cancer," Journal of the National Cancer Institute, vol. 92, no. 14, pp. 1126-1135, 2000.

[30] E. Wiechec, "Implications of genomic instability in the diagnosis and treatment of breast cancer," Expert Review of Molecular Diagnostics, vol. 11, no. 4, pp. 445-453, 2011. 


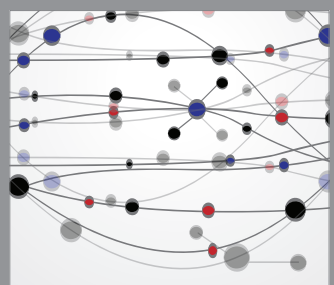

The Scientific World Journal
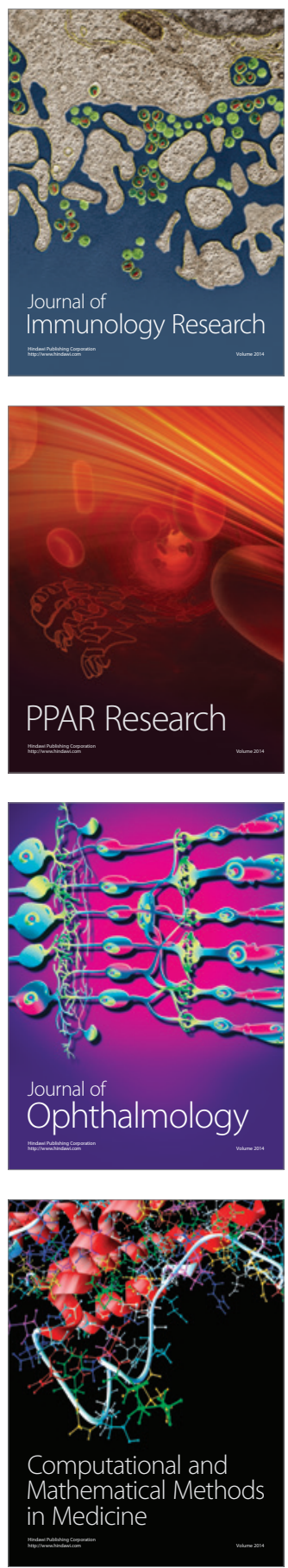

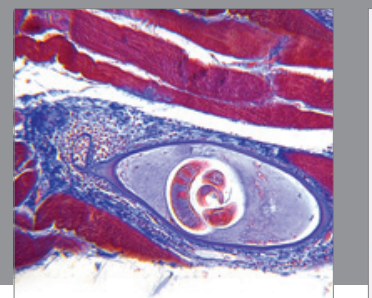

Gastroenterology

Research and Practice
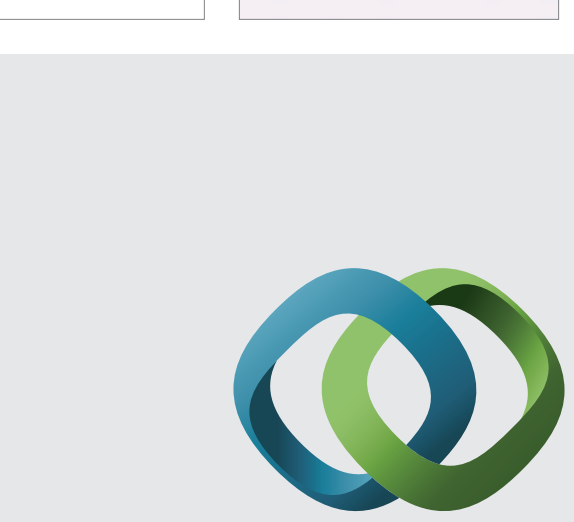

\section{Hindawi}

Submit your manuscripts at

http://www.hindawi.com
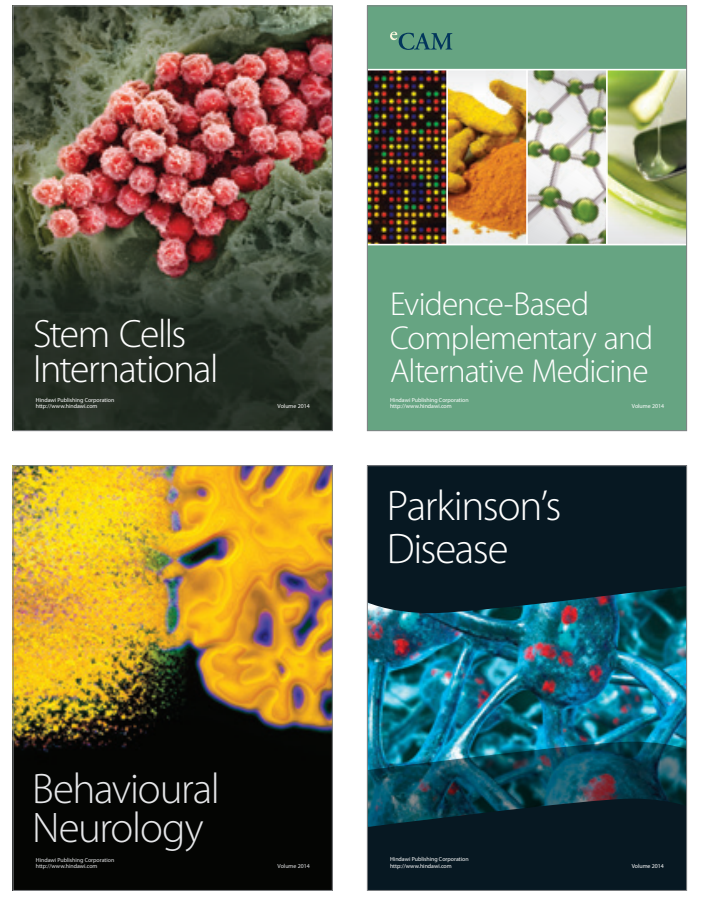
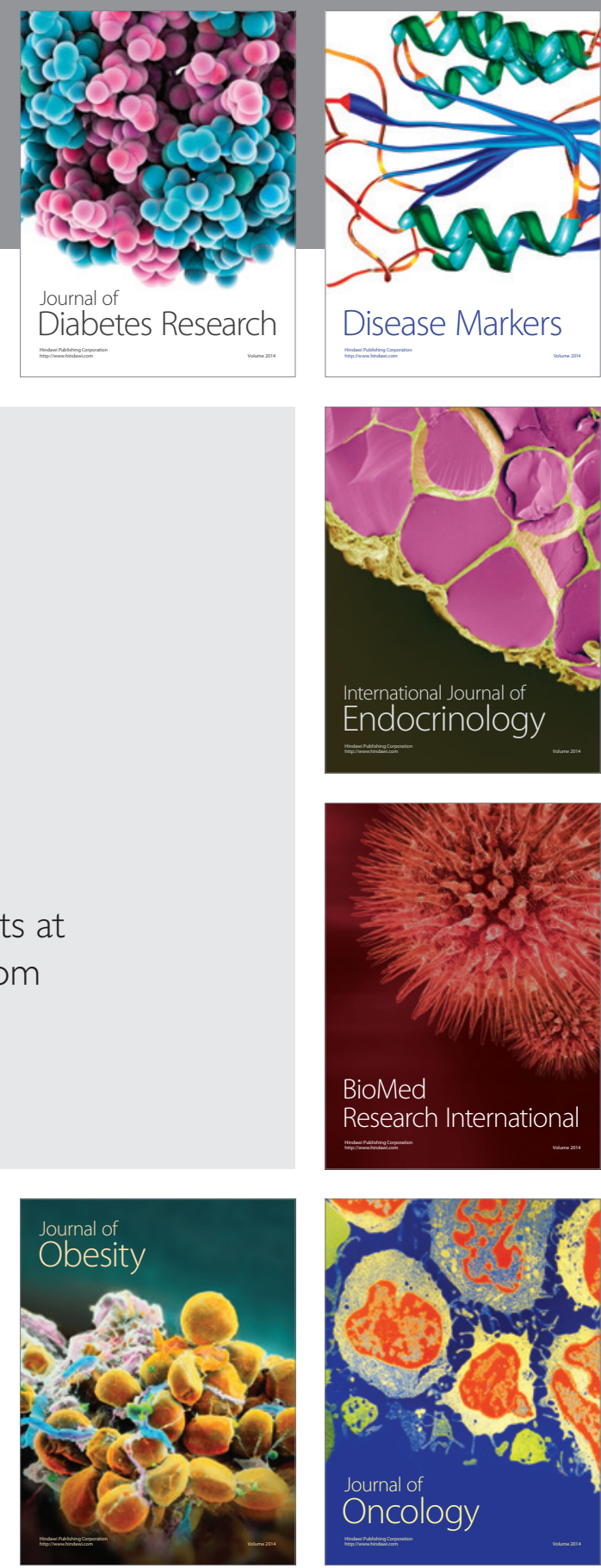

Disease Markers
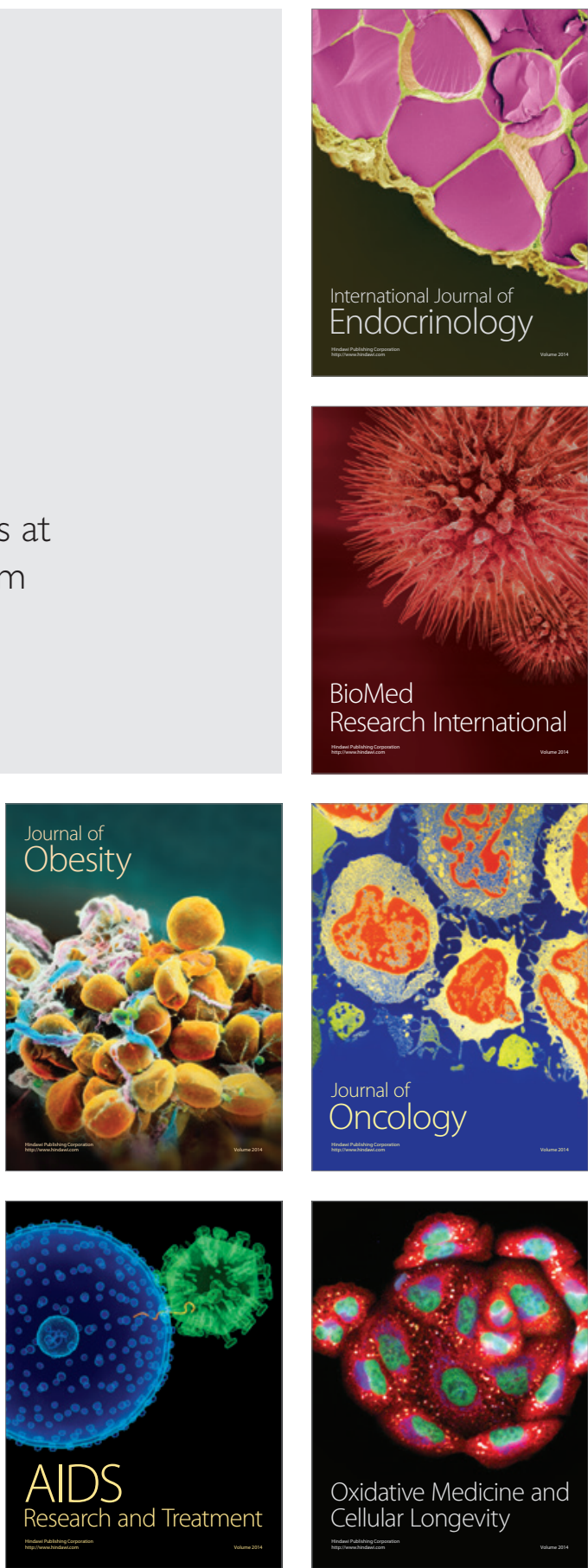